\title{
CONSTRUCTION OF MASTER RECESSION CURVE USING GENETIC ALGORITHMS
}

\author{
MILOŠ GREGOR ${ }^{1,2)}$, PETER MALÍK ${ }^{1)}$ \\ ${ }^{1)}$ Department of Hydrogeology and Geothermal Energy, State Geological Institute of Dionýz Štúr - Geological Survey of Slovak \\ Republic, Mlynská dolina 1, 81704 Bratislava, Slovakia; Mailto: milos.gregor@hydrooffice.org; peter.malik@geology.sk \\ ${ }^{2)}$ Department of Hydrogeology, Faculty of Natural Sciences - Comenius University, Mlynská dolina, 84215 Bratislava, Slovakia
}

The article describes a new methodology of using genetic algorithms to assemble a natural time series of discharge recession, from which a master recession curve can be interpreted both for streams and for springs. Presented approach can avoid obstacles such as limited time-series datasets, incomplete recessions or too many recessionary segments in many recession series, different time intervals of observations (daily or weekly frequencies). Short time-series intervals, imprecise or mistaken measurements and different types of datasets (averaged or directly measured data) are taken into account as well. Even rough measurements of discharges with inaccurate sensing range can be analysed, if sufficiently long observation is available. Complicated hydrograph shapes in the case of e.g. karstic springs (often caused by combination of laminar and turbulent discharge sub-regimes due to karst network settings) can be processed as well. Subsequent construction of master recession curve is much easier an offers better conditions for its interpretation. Presented algorithm was already implemented to a programme solution, completed on the user form.

KEY WORDS: Recession Analysis, Master Recession Curve, Hybrid Genetic Algorithms, Evolutional Algorithms, HydroOffice.

Miloš Gregor, Peter Malík: ZOSTAVOVANIE TYPOVEJ VÝTOKOVEJ ČIARY POMOCOU GENETICKÝCH ALGORITMOV. J. Hydrol. Hydromech., 60, 2012, 1; 30 lit., 15 obr.

Článok opisuje novú metodiku využitia genetických algoritmov pre kompozíciu úplných a prirodzených časových radov poklesu prietokov na povrchových tokoch alebo výdatností prameňov v čase bez dopíňania hydrologických systémov/infiltračných oblastí, ktoré možno následne interpretovat výtokovou čiarou. Prezentovaná metodika umožňuje prekonanie častých problémov, akými sú krátke alebo nekompletné časové rady, neúplne zaznamenané výtokové procesy alebo naopak príliš mnoho segmentov v množstve čiastkových poklesových radov, rozdielne (denné alebo týždenné) intervaly pozorovaní, nepresné alebo chybné merania, alebo rozdielne typy údajov (priemerné alebo priamo merané hodnoty). Ak sú k dispozícii pozorovania $\mathrm{z}$ dostatočne dlhého časového intervalu, metóda umožňuje aj spracovanie pozorovaní s vysokou mierou nepresnosti odčítania hodnôt prietokov alebo výdatností. Komplikované tvary hydrogramov, aké sú časté najmä v prípadoch krasových prameňov (často spôsobované kombináciou účinku laminárnych a turbulentných subrežimov v dôsledku zložitej štruktúry krasových obehových ciest) taktiež nepredstavujú problém pri automatizovanom skladaní výtokových časových radov. Následné zostavenie výtokových čiar je potom ovel'a jednoduchšie a poskytuje lepšie podmienky pri ich interpretácii. Prezentovaný algoritmus bol už realizovaný v rámci programového riešenia, zostaveného do užívatel'skej podoby, takže opísanú metódu možno aplikovat’ aj bez znalostí programovania.

KLUÚČOVÉ SLOVÁ: analýza výtokových čiar, reprezentatívna výtoková čiara, hybridné genetické algoritmy, evolučné algoritmy, HydroOffice.

\section{Introduction}

Analysis of recession curves is often used method in hydrological practice, which provides a wide range of results interpretations. Although the principles of hydrograph analyses are developed for more than one and a half of a century (Boussinesq,
1877, 1904; Maillet, 1905; Horton, 1933; Barnes, 1939; Cooper and Rorabaugh, 1963; Schoeller, 1965; Drogue, 1967; Kullman, 1980, 1990; Padilla et al., 1994; Griffiths and Clausen, 1997; Kovács, 2003; Gregor, 2008), mainly the introduction of computer techniques enhanced their applications in broader field of hydrology and hydrogeology. Such 
alternative applications we can find for example in the analysis of hydrological drought (Tallaksen and van Lanen, 2004), groundwater vulnerability (Kullman, 2000; Malík, 2007) and in the separation of runoff components, e.g. baseflow separation (Malík, 2010).

The main advantage of recession curves analyses is that as an output, a set of quantitative parameters attributed to drainage mechanisms is received. With given recession coefficients and initial discharges values, both total runoff and partial runoff segments (sub-regimes) can be completely described. Such a mathematical description can be then applied starting from the state of maximum documented water saturation of the system and finishing at a stage of maximal documented emptying of the drained structure. Usual problem with application of individual recession curves, derived from limited time periods, is that in most cases they describe the process only partially, depending on the limiting water stages of these periods. To cover all possible solutions, different methods of composing individual curves into a single master recession curve (with the longest course and covering all documented water stages) were created. Various methods, gradually developed for such master recession curve assembling, have different application possibilities, and restrictions as well. This article introduces a new method of putting together a natural time series of discharge recession, based on optimization techniques, which tends to solve many of the shortcomings and gaps of the existing methods (Lamb and Beven, 1997; Rutlege, 1998; Posavec et al., 2006). Subsequent construction of master recession curve is much easier and offers better conditions for its interpretation.

\section{Constraints and options of assembling complete recession in discharge time series}

The process of discharge recession is usually manifested by slightly different hydrograph shapes, as runoff from a catchment (or a hydrogeological structure) is physically determined by two types of impacts and parameters. First, there are static properties of the environment (as e.g. geometry, aquifer hydraulic properties, catchment slopes), which remain constant over the time. Second, there are dynamic properties, such as the degree of structure (rock \& soil mass) repletion by water, rate of the water infiltration, rainfall/evapotranspiration and its variation in time and space, possible anthropogenic influence and other time-dependent factors. In a rough approach it may look like the recession discharges have generally a similar time course, but the combination of the aforementioned parameters causes that each course of discharge recession is unique and differs in absolute values (recession coefficients, discharges). The influence of the dynamic parameters described is projected on the complexity of recession processes described within even a simple watershed and represents the main problem to be solved in the process of master recession curve assembling (Tallaksen, 1995). However, proper assemblage of recessional discharge successions represents the main task that should be completed before the recession curve analyses.

Even under simple conditions, the influence of static and dynamic physical properties of catchment/hydrogeological structure on character of discharge recession is manifested in considerable variability of relations between individual sequences of discharges in time. Dynamically changing physical properties lead to resulting set of differently shaped discharge recessions. Also under similar saturation conditions, complexity of the static physical properties (such as karstic aquifers as shown by e.g. Kullman, 1980, 1990) may lead to nonuniformly distributed discharge values in time series. Only proper compilation of discharge/time successions into one set of values, completely describing the whole process of recession, can lead to detection of all discharge sub-regimes and their characterisation by perhaps several matching equations or equation types.

Apart from naturally conditioned complexities of the measured subject (discharge recession), we should overcome obstacles induced by the limitations of measurement itself - mainly the accuracy of discharge measurements and measurements' frequency. Often, especially at low discharges, the visible change between two readings in time is too small to be recorded. Although the real discharge values decrease, for various reasons the recession (in better case) is recorded in the form of "long steps". On the other hand, if the typical flood wave duration in comparison with the frequency of readings is too short, so the probability of recording maximal discharge is also limited, especially in the case of old archive data or derived data (e.g. smoothed into daily averages). This represents a serious deficiency especially in the case of groundwater monitoring, where many objects (springs or wells) are monitored only on weekly bases. When analysing specific operational groundwater monitoring objects, another feature appears: availability 
of only short discharge time-series (e.g. not longer for more than two years of observations) with very few discharge data records. It is very probable, that within such a limited time of observations, the extreme values were omitted from the available set of results.

Several methods have been developed to construct a master recession curve from a set of shorter recessions (Tallaksen and van Lanen, 2004). The simplest one is a manual creation of a master recession curve (the matching strip method; Toebes and Strang, 1964). Using this method, all recession segments are shown on a single chart. They are moved on the horizontal timeline until they form one, more or less compact, master recession curve. The main deficiency of this method is the timeconsuming processing and subjectivity. Usually, different authors obtain different recession results, depending on their previous experience. Evaluation of discharge threshold value, from which the recession starts (not always maximum) and the evaluation of recession period is often subjective, various authors show various criteria (Tallaksen 1995).

Lamb and Beven (1997) had developed an automated tool in Matlab, which allows the use of a prototype curve to master recession curve assembling. A similar procedure is also included in RECESS program (Rutlege, 1998). However, the program allows creation of the master recession curve only for exponential recession models and it is not applicable for complex recession systems. Another approach was presented by Posavec et al. (2006). The authors created a macro in MS Excel, which uses for this purpose the results of flow duration curve. Discharges on the discharge probability (flow duration) curve are divided into three sections and the resulting master recession curve is composed by assigning the partial recession curves to each defined sections. The macro enables the analyses of even more complex types of recession, but requires exact measurements and sufficient number of unaffected recession curves (discharge decrease unaffected by additional recharge within the catchment/hydrogeological structure).

The aforementioned overview of methods shows constraints of the assembling process of the most probable unaffected sequence of discharge recession. In the search for new efficient solutions, previously described specific problems of master recession curves assembling were defined as the basic criteria that the new solution should take into account. Such a method must be applicable in all specific conditions encountered especially in ground- water hydrology, such as inaccurate measurement or small population or low frequency of measurements. The method must enable compilation of one successive set of discharge vs. time values, describing the complete natural process of recession from the highest to the lowest measured discharge values. An effort was also undertaken to eliminate possible effects of dynamic factors described. The authors have tested variety of aforementioned methods of construction of master recession curve, but genetic algorithms described in this article proved to provide the best results.

\section{Genetic algorithms}

Genetic algorithms are, together with neural networks, expert systems and methods of chaos theory, considered to be a part of artificial intelligence group of methods. Genetic algorithms are based on the principles of Darwin's evolutionary theory and can be described as stochastic search methods. They are based on the mechanism of natural selection and on the principles of genetics. Their practical use is wide - they are mainly applied in search for global extremes of functions, encryption, networks optimizing, or for the predicting of chemical substances structure and properties. In the field of hydrology and hydrogeology, their application was described e.g. in:

- a parallel evolutionary calibration of hydrological and snow models (e.g. Sharma et al., 2006; Holko et al., 2003);

- determination of rock hydraulic parameters from the pumping tests (Samuel and Jha, 2003);

- optimizing of water resources abstraction (Chiu et al., 2007, Čistý and Bajtek, 2009);

- contamination transport modelling (Bayer and Finkel, 2004).

The main principle applied within the genetic algorithm procedure is the creation of initial population of random solutions of the defined problem at the beginning (Hynek, 2000). Each solution in the population is presented as data structure (e.g. data array), what allows us to effectively save the information about individual solution. Individual solutions are tested and evaluated towards achieving a defined goal. Subsequently, a new population is created from the existing population of solutions. Better solutions from the previous population have higher probability of transition into a new generation. In the creation process of new generation of solutions, two individual solutions are randomly 
selected, but solution with better rating has a higher probability to be selected. For this purpose, a "roulette mechanism" is frequently used, where solutions with higher rating obtain bigger slice from the roundel. After defined crossing is performed, a newly created solution takes the properties from both two solutions from previous generation. This new individual solution presents a random combination of the parental generation properties. During the crossing process, a random mutation which randomly changes a part of the final solution also happens. This mutation process, however, occurs only with very low probability.

Gradually, by help of evolution cycles repetition, a solution that is very close to the ideal one is evolved. Described evolutionary process can be stopped either by pre-described number of evolutionary cycles in the set, or when a sufficiently accurate solution is reached, or even if the population losses its ability to converge to the ideal solution.

\section{Application of genetic algorithms for assembling of discharge recession time series}

Here, the implementation of the aforementioned principles and their strong hybridization (adjustment of parameters) for the needs of assembling of discharge recession time series is described. Prior to the creation of the most probable unaffected discharge recession (sequence of discharges vs. time) and its subsequent interpretation by master recession curve, a detailed study of hydrogram should be performed. A set of individual discharge recessional successions should be selected from the all recorded discharge time series. To fulfil the requirements of the described algorithm, it is not necessary to focus on selection of merely extra long recession periods, unaffected by rainfall. Shorter depleting sections can support the success of final solution as well. On the other hand, selected recession periods should describe the whole process of recession, from the highest to the lowest documented discharge values (Fig. 1).

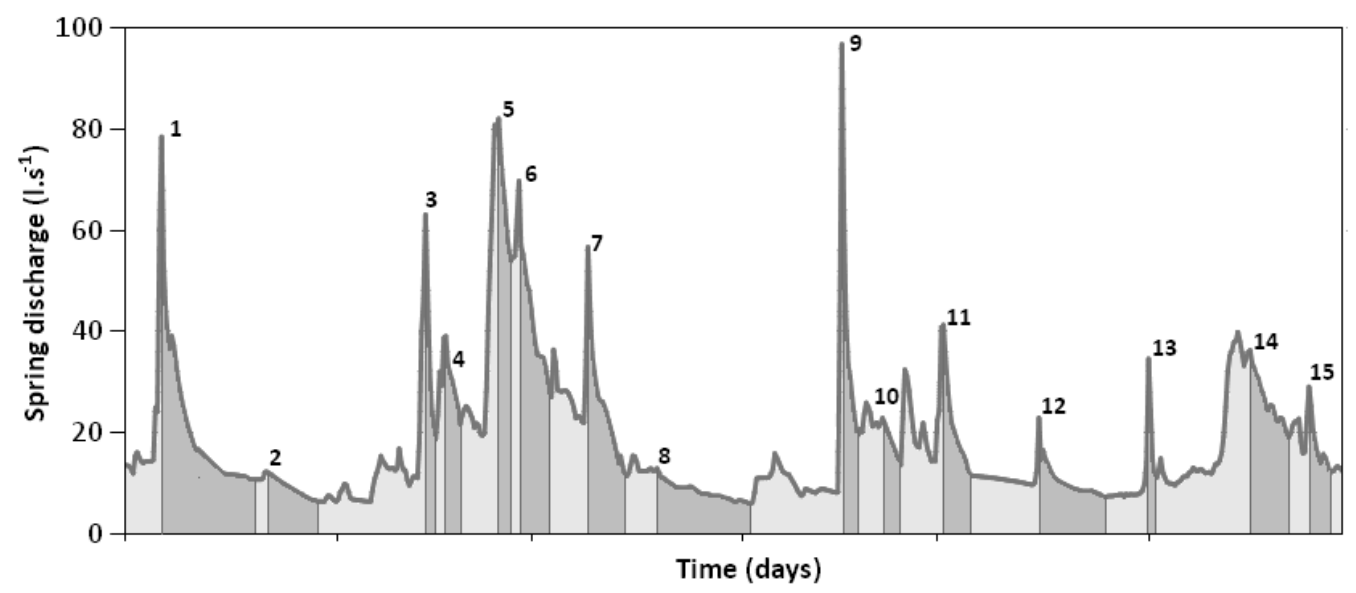

Fig. 1. Selection of discharge recessional successions and its sections from discharge time series.

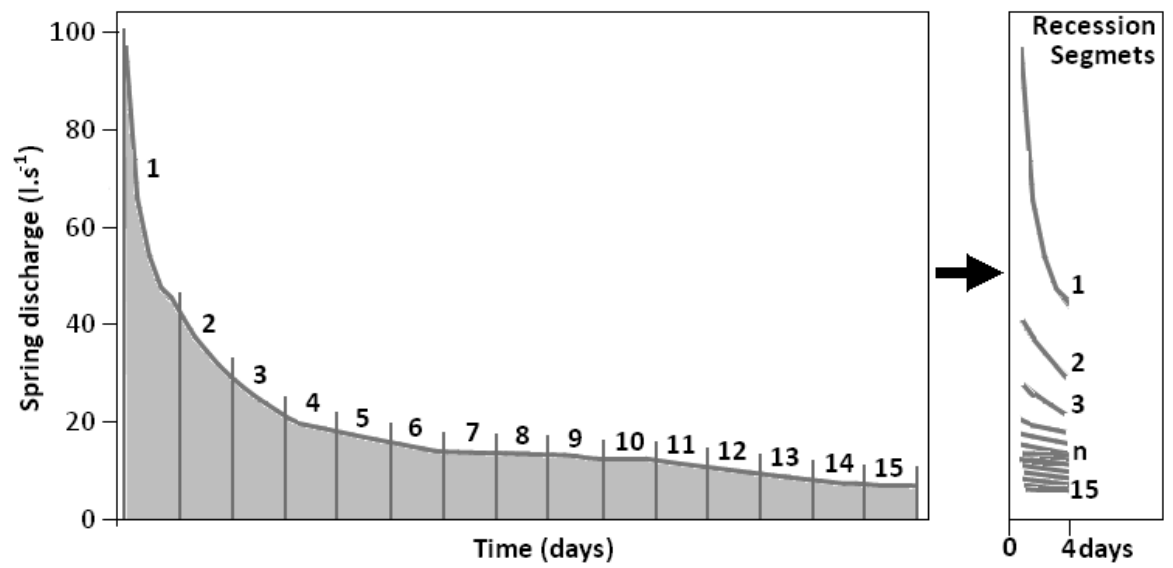

Fig. 2. Division of a selected recession into $N$-days segments. 
Second step of construction of the most probable unaffected recessional discharge succession is illustrated in Fig. 2. In this step, each selected recession is divided into a corresponding number of individual $N$-day segments. During the development and testing phase of the described method, the algorithm proved to be most effective when the division of selected hydrograph depleting sections into 4days long segments was applied.

These segments define changes in discharge in short time periods. By such a segmentation of recession intervals into small segments and their further processing, the method can overcome the "shading influence" of the dynamic factors (as e.g. recharge and runoff variability). These segments are later used in the assemblage process to create the most probable unaffected discharge recession sequence, which can be later described by the master recession curves (MRC).

Ideally, resulting set of recessing discharges is assembled by simple moving of the defined short segments on the timeline, until they will together create one single line. In practice, this process is not so simple and for the automatic shifting of separate segments on the timeline, genetic algorithms are used.

Before the start of the use of genetic algorithms, the structure of each separate solution in the population of solutions should be defined. Example of such structure of individual solution is shown on Fig. 3. After splitting of selected discharge recession intervals, several hundred segments are usually obtained. Each individual segment is the member of the population of solutions, and in the population of solutions can be defined by two-dimensional array (table). In this data structure the position of each recession segment is defined in one table row. The first column here identifies every segment by unique number value (integer). In the second column one can find the value which marks the segment's shift on the timeline (Fig. 3). This very brief structure for storing the results of each solution in the population is sufficient and enables the effective run of genetic algorithm.

All the solutions are in the same, previously described way defined within a population of solutions. Depending on the number of pre-defined solutions in the population (by the user), corresponding number of data structures is created. In these, individual solutions will be defined. The first population is created pseudo-randomly. The maximal time shift $t_{\max }$ is pre-defined before the run of the algorithm - and the movement of segments in evolution process automatically does not overstep this value.

A random shift between the initial time $t_{0}$ and maximal time $t_{\max }$ is then generated for each segment. As it can be prejudiced that on the resulting discharge recession set, segments with high discharge values will appear before segments with lower values, we can influence the range of the possible random time shift accordingly. In the process of random shift generating for the initial population, the range of possible random time shift values increases with decreasing values of discharges in segments. After the initial - first generation had been created, individual solutions are assessed from the "best-fit" point of view. As an assessment tool for the accuracy of solutions, the segments' dispersion area (Fig. 4) is calculated for each solution.

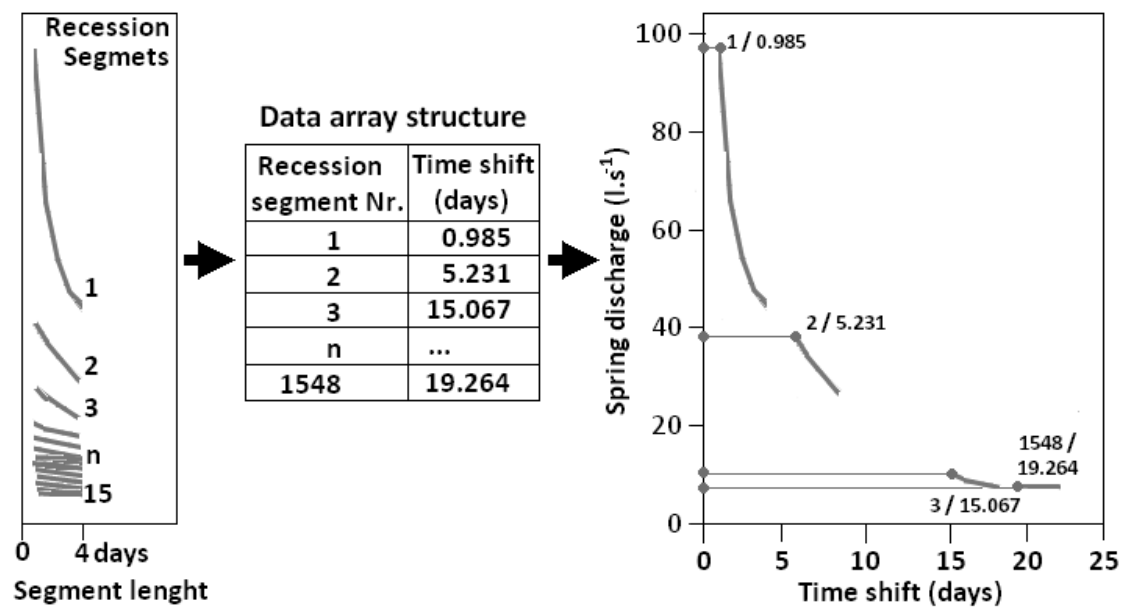

Fig. 3. Definition of data structure for each individual solution in the population of solutions. 


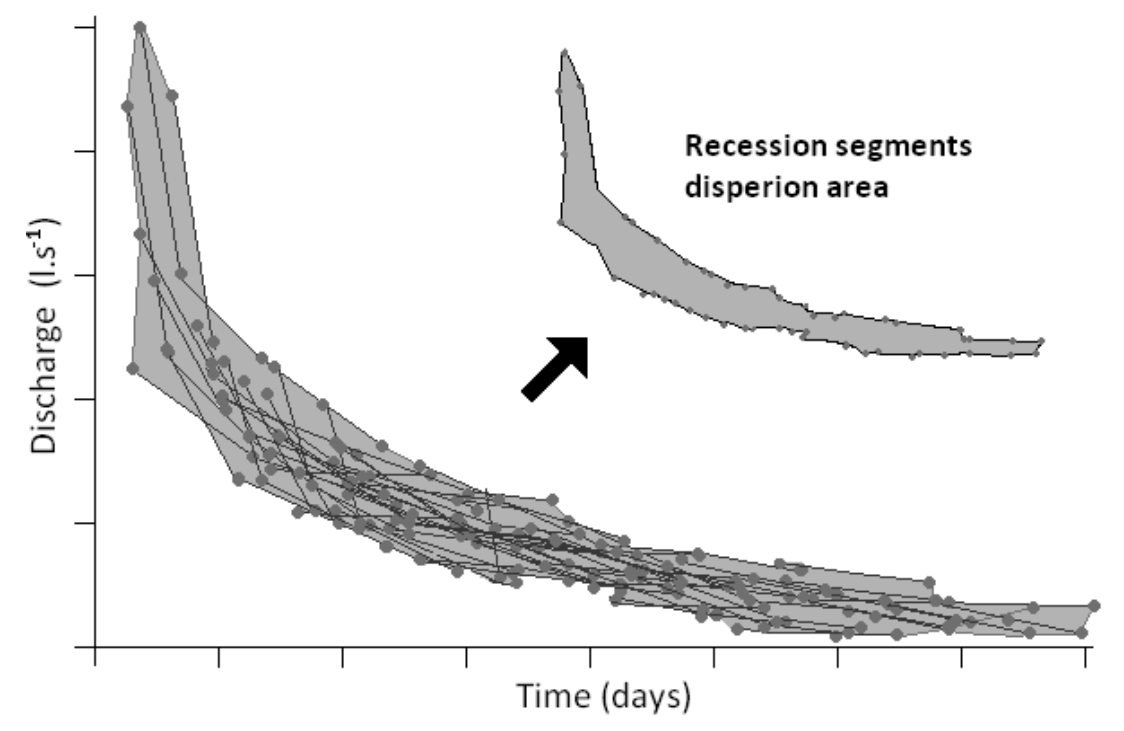

Fig. 4. Definition of segments' dispersion area.

Segments' dispersion value defines the area of variance that is created by individual segments on the chart. This value is smaller for the better solution; the best solution has the lowest segments' dispersion value. Following the assessment of solutions in one generation, solutions for the next generation are being prepared. To do this, two solutions are randomly selected from the current generation by the use of "roulette selection mechanism", where better solutions are equipped with higher probability to be used as a source for creating the solutions in next generation. After the two solutions from the current generation of solutions have been selected, only one solution for the next generation based on these - is created by the crossing process. Several methods can be applied for the crossing process, but while "single point crossover" is mostly applied by many solutions, in our case a method of "crossing by averaging" (Fig. 5) is suggested.

In this case, a new individual solution copies the data structure, while the time shift for each segment is calculated as an average of the previous two solutions. In addition to the crossing process, also the mutation processes (Fig. 6) is incorporated in the evolution. Usually the mutation occurs with very low probability (e.g. 1 mutation per 1000 crossings), but in our case, this approach was modified hybridized, as the mutation occurs at every crossing of solutions. Such an approach is frequently applied within a method of artificial immune system. In our case, this approach was used to avoid the development of exactly equal solutions within one population. This allows the reduction of the conversion rate of calculation and the population during the evolution remains relatively variable. Mutation is applied after the averaging of two solutions. By this procedure we receive a new position of segment within a dispersion area. If the first segment point is situated on the bottom half of the dispersion area, the mutation value is added. If it is located in the upper half, the mutation value will be subtracted (Fig. 6 - bottom).

Mutation value is just a random value generated from the defined interval $\left\langle t_{0}, t_{\mathrm{def}}\right\rangle$. If this range of random values would be chosen to be too low, also the populations' variability would be relatively low. Conversely, if the range would be chosen to be too wide, after several cycles of evolution the development of the ultimate solution would stop, as the mutation would not permit to reduce the value of segments' dispersion area. Therefore, the predefined range of values, from which random mutation values can be created, gradually decreases with the development of the evolutional cycles. It is also possible to set the maximal range of mutations and its gradual reduction within the run of algorithm.

This procedure will gradually create new and new solutions, which are continuously re-assessed by calculating of the segments' dispersion area. The evolutionary cycle is repeated until the number of its runs reaches a pre-defined number of cycles. Application of this procedure leads gradually to creation of solution corresponding to the resulting most probable unaffected recessional discharge succession from the initial pseudo-random generation. 


\begin{tabular}{|c|c|c|c|c|c|c|c|c|c|c|c|c|c|}
\hline \multirow{2}{*}{\multicolumn{3}{|c|}{$\begin{array}{l}\text { 1. selected solution } \\
\text { from generation }\end{array}$}} & \multicolumn{2}{|l|}{1} & \multicolumn{2}{|l|}{2} & 3 & \multicolumn{2}{|c|}{4} & \multicolumn{2}{|l|}{5} & $n$ & 1548 \\
\hline & & & \multicolumn{2}{|c|}{0.25} & \multicolumn{2}{|c|}{0.95} & 15.40 & \multicolumn{2}{|c|}{65.45} & \multicolumn{2}{|c|}{22.68} & $\ldots$ & 54.82 \\
\hline \multirow{2}{*}{\multicolumn{3}{|c|}{$\begin{array}{l}\text { 2. selected solution } \\
\text { from generation }\end{array}$}} & \multicolumn{2}{|l|}{1} & \multicolumn{2}{|l|}{2} & 3 & \multicolumn{2}{|c|}{4} & \multicolumn{2}{|l|}{5} & $n$ & 1548 \\
\hline & & & \multicolumn{2}{|c|}{1.87} & \multicolumn{2}{|c|}{6.98} & 22.47 & \multicolumn{2}{|c|}{88.89} & 14.51 & \multicolumn{2}{|r|}{$\ldots$} & 124.34 \\
\hline \multicolumn{11}{|c|}{$\begin{array}{l}\text { Newly-created solution } \\
\text { in new generation }\end{array}$} & \multirow{3}{*}{\multicolumn{3}{|c|}{$\begin{array}{l}\text { Crossover by } \\
\text { averaging } \\
\text { + mutation }\end{array}$}} \\
\hline 1 & 2 & \multirow{2}{*}{\multicolumn{2}{|c|}{$\begin{array}{l}3 \\
18,34\end{array}$}} & \multirow{2}{*}{\multicolumn{2}{|c|}{$\begin{array}{l}4 \\
77.17\end{array}$}} & \multicolumn{2}{|l|}{5} & $n$ & \multicolumn{2}{|c|}{1548} & & & \\
\hline \multirow[t]{3}{*}{1.86} & 3.97 & & & & & 18.60 & & $\ldots$ & \multicolumn{2}{|c|}{89.58} & & & \\
\hline & & & & & & & & \multirow{2}{*}{\multicolumn{3}{|c|}{ Description }} & 5 & & gment $\mathrm{Nr}$. \\
\hline & & & & & & & & & & & 14.51 & & 5) \\
\hline
\end{tabular}

Fig. 5. Description of "crossing by averaging" method, used for creating of new solution.

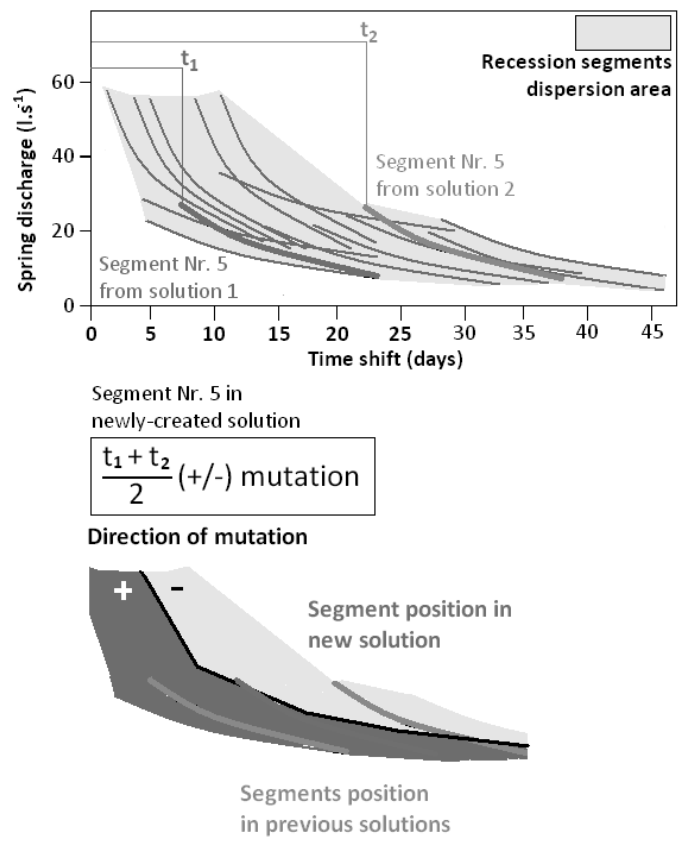

Fig. 6. Description of mutation process application on the creating of new solution.

\section{Experience with algorithm implementation}

Practical application of the described process of assembling of the most probable unaffected recessional discharge succession was implemented into an executable computer program. For this purpose, a freely accessible software modular tool HydroOffice (http://www.hydrooffice.org) developed by one of the authors, was used. This also includes a standalone application "RC", designed for recession curves separation and analysis (Fig. 7).

For hybridized genetic algorithm application, a separate program window was created, where the evolutionary assemblage of the probable natural discharge recession sequence can be completed (Fig. 8).
Discharge time series are processed and recessional sequences (or their parts) selected automatically or manually in the main program window. Then, a separate tool for further processing can be launched. Within this, at first discharge recessional successions are divided into individual $\mathrm{N}$-days segments, both manually or automatically. The segments are adjusted while displayed in a chart. The adjustment consists in automatic deletion of short segments or deletion of constant discharge segments. Such an adjustment (Fig. 9) is necessary for proper start of evolutionary assembling.

Before the assembling process by application of genetic algorithm, all necessary parameters as shown in the Fig. 10 should be set. At first, the number of evolution generations is determined. From experience, optimal number of generations required for the use of genetic algorithms is frequently around 200. Thanks the hybridization of algorithm this value is significantly lower in our approach, and ranges from 50 to 100 . Another parameter to be set by the user is the number of individuals (i.e. solutions in generation). Predefined minimum number of individuals is 15 , its optimal value is generally 15 to 50 . Increased number of individuals in generation and higher number of generations increases the accuracy of solution, but also prolongs computing time.

Another input parameter represents the probability of crossing, which is defined in a range from 0 (no crossing) to 1 (crossing is always applied). Optimal value of this parameter seems to be 0.9 and usually there is no need to change this value. Parameter "Maximal length of a MRC" defines maximum possible length of resulting sequence of discharge recession (in a time span). Its value should be chosen approximately, by taking into account the length of individual discharge recession sequences selected at the beginning of processing. 

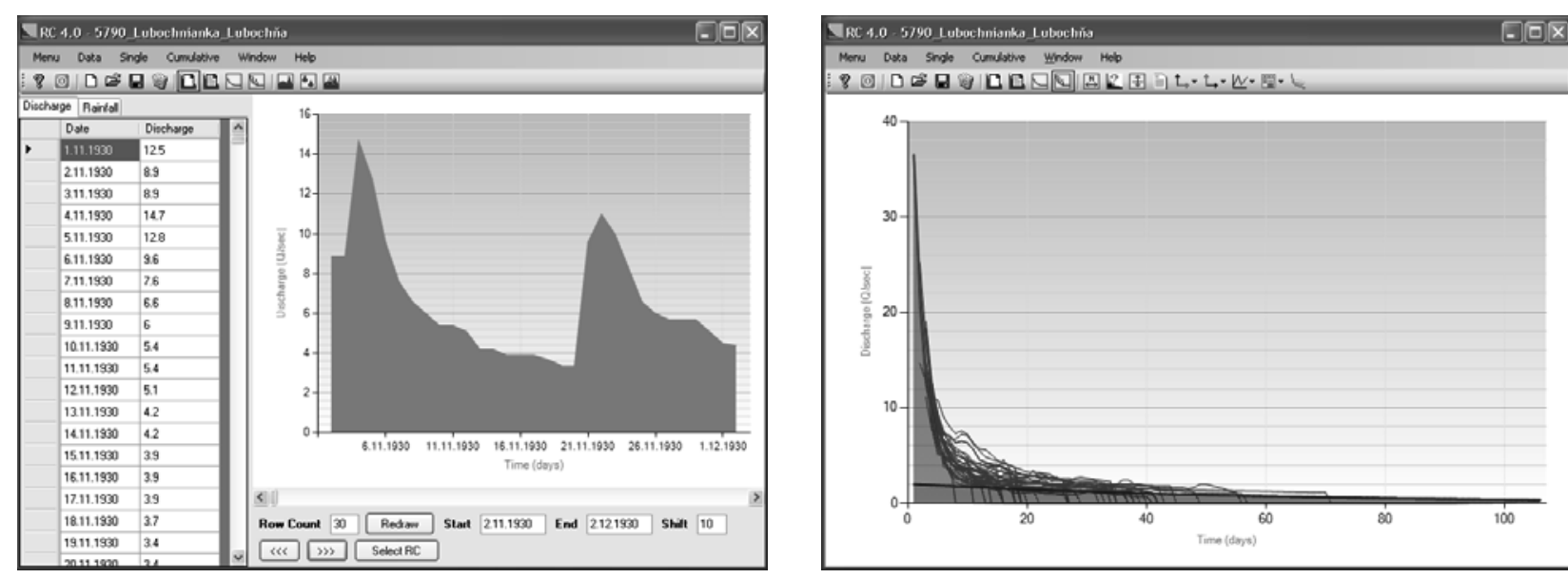

Fig. 7. Usual software windows of the RC 4.0 program for discharge recession separation and analysis.

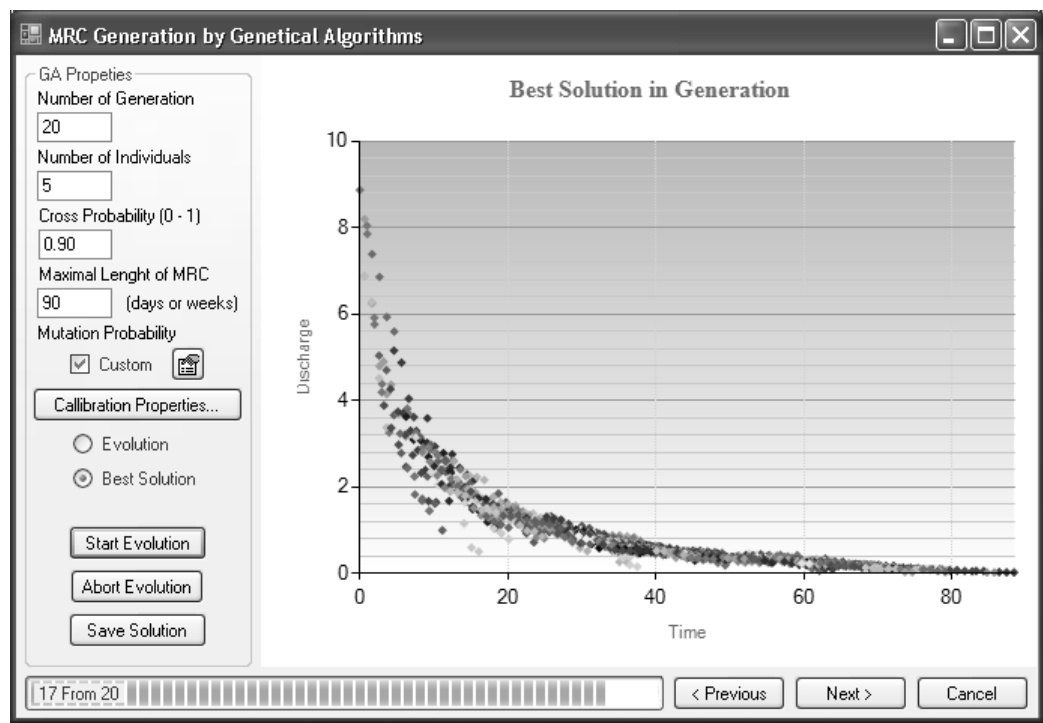

Fig. 8. Separate window for assembling of individual discharge recessional sequences by hybrid genetic algorithm. Various sets of individual recessions (discharge vs. time) are distinguished by points of the same colour.
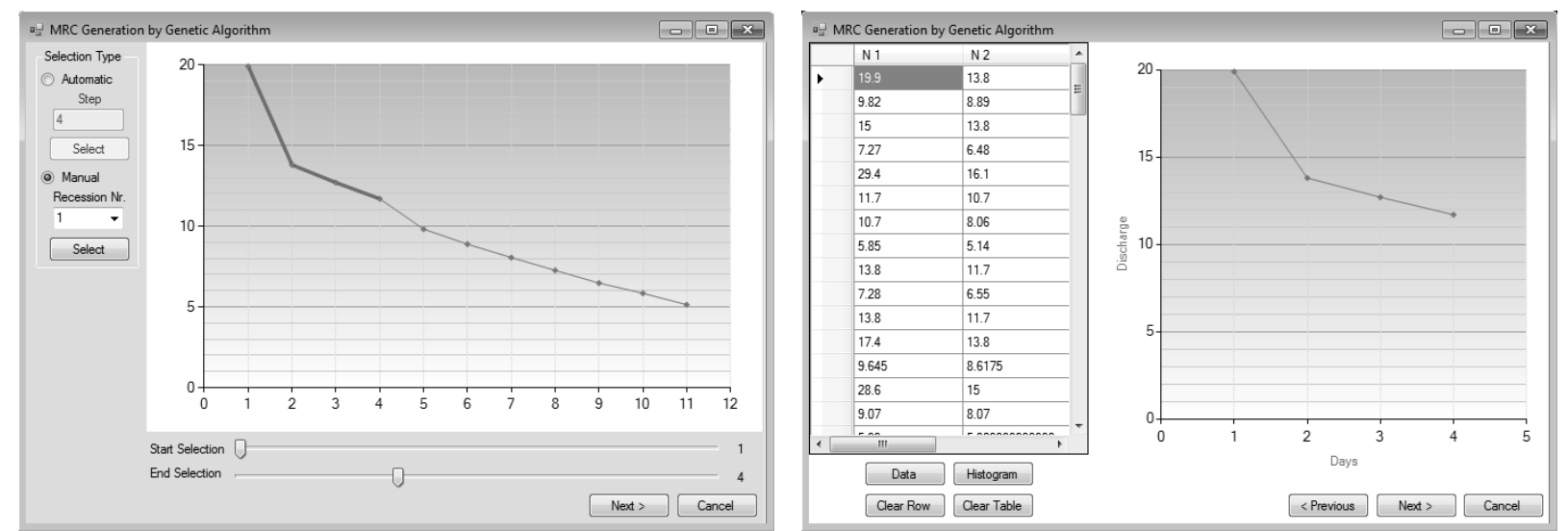

Fig. 9. Pre-processing of recession segments (left - manual or automatic segmentation of recessional sequences; right - table and visualization of prepared recession segments). 


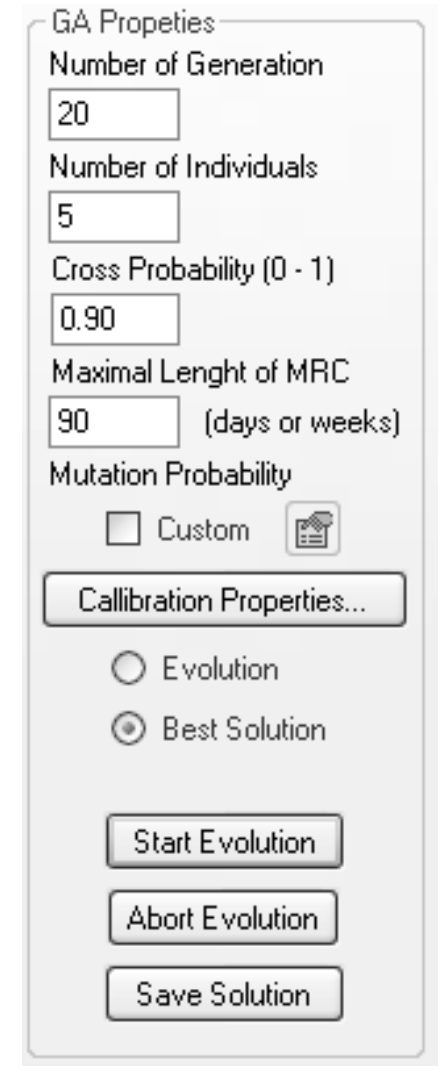

Fig. 10. Adjustment of parameters necessary for the evolutionary assembling process of the most probable unaffected natural discharge recession sequence.

The last parameter, which is necessary to define, is the mutation. Mutation is determined by three values (Fig. 11). The first one is the initial range (maximal starting dispersion of mutation in days), from which the mutation shift is generated. By "declination coefficient" the decrease of the initial range in individual evolution cycles is defined, while the nature of this decrease can be defined as linear or exponential.

After all aforementioned parameters are defined, the calculation run can start - its state is monitored directly on a chart or in the bottom progress bar. When monitoring status of evolutionary process on the chart, it is possible to choose between two options: displaying the best solution in actually computed generation (Fig. 12, left), or displaying the dispersion area changes in average solution and the best solution in successive generations (Fig. 12, right). Evolutionary cycle terminates either after reaching of pre-defined number of cycles, or by manual abortion.

Currently, the completed solution can be saved and the whole procedure can be repeated with different parameters describing the algorithm. It is possible to choose the best (most appropriate) from several solutions, export it back to the main program window, and continue with further processing - construction of master recession curve by its description by equations set of parameters in respective equations.

\section{Examples of assembled recessional discharge time series and further construction of master recession curves}

The described method was tested and used at many very variable conditions to assemble the most probable natural sequence of discharge recession in universal time elapsed from the discharge maximum. In addition, recession curves were constructed from the most probable natural discharge recessional succession, received as result of hybridized genetic algorithm run. Both stream discharge time series (daily or shorter time step), were tested as well as a number of spring yield data (daily or weekly time step). An example of gradual algorithm run is shown in Fig. 13. It starts with 10 randomly generated solutions (initial population in the upper left corner), following pictures depict the best solution in successive evolutionary cycles (generations), while the last - bottom right picture - shows the final result of described algorithm, set of the most probable natural sequence of discharge recession.

Figs. 14 and 15 show examples of assembled recessional discharge sequences, generated from different hydrological environments. Fig. 14 shows the set constructed for a karstic spring Dovalka in Muráň (Central Slovakia; N48.7403; E20.0450). Further construction of master recession curve had revealed three runoff sub-regimes of turbulent flow type, typical for karstic springs (Kullman, 1990). These are visible on the rounded course of discharge recession points on the log plot here (on the normal plot of discharge vs. time should appear as straight lines). According to this, Dovalka is a typical overflowing karstic spring, active only after major recharge events. Very probably, the dewatered karstic aquifer can be characterised by the existence of periodically flooded large karstic channels in various stages of karst development. There are no signs of presence of a sub-regime dewatering the phreatic fractured zone, with permanent water table.

Fig. 15 shows the assembled recessional discharge sequences, representing the most probable 
normal course of recession of the Lubochnianka creek gauged in L'ubochňa (Northern Slovakia; $\left.\mathrm{N} 49.1226^{\circ} ; \mathrm{E} 19.1686^{\circ}\right)$. When analysing the master recession curve, two runoff sub-regimes were indicated. In recession analyses, they can be described by two exponential equations with different parameters. Each equation represents a different subregime. Identified sub-regime with lower exponent value was linked to the baseflow, representing the deeper groundwater circulation within the water- shed. "Steeper" sub-regime (with higher exponent value) then represents the subsurface flow in the watershed.

Both two presented examples of discharge recession assemblages were obtained from daily measurement frequency time series. The described algorithm was with equal success tested also on a weekly type of time series input data (usual for groundwater measurements in Slovakia).

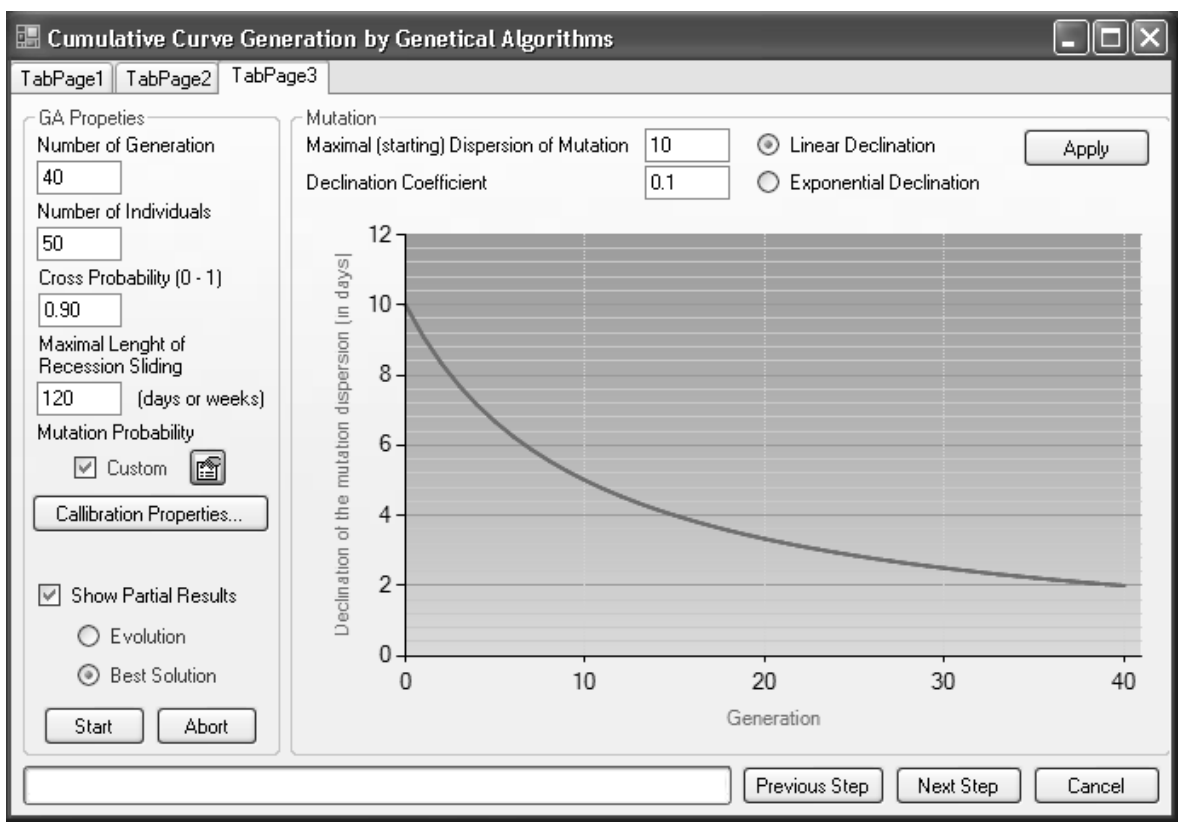

Fig. 11. Determination of mutation decrease in the evolution process by three input values.

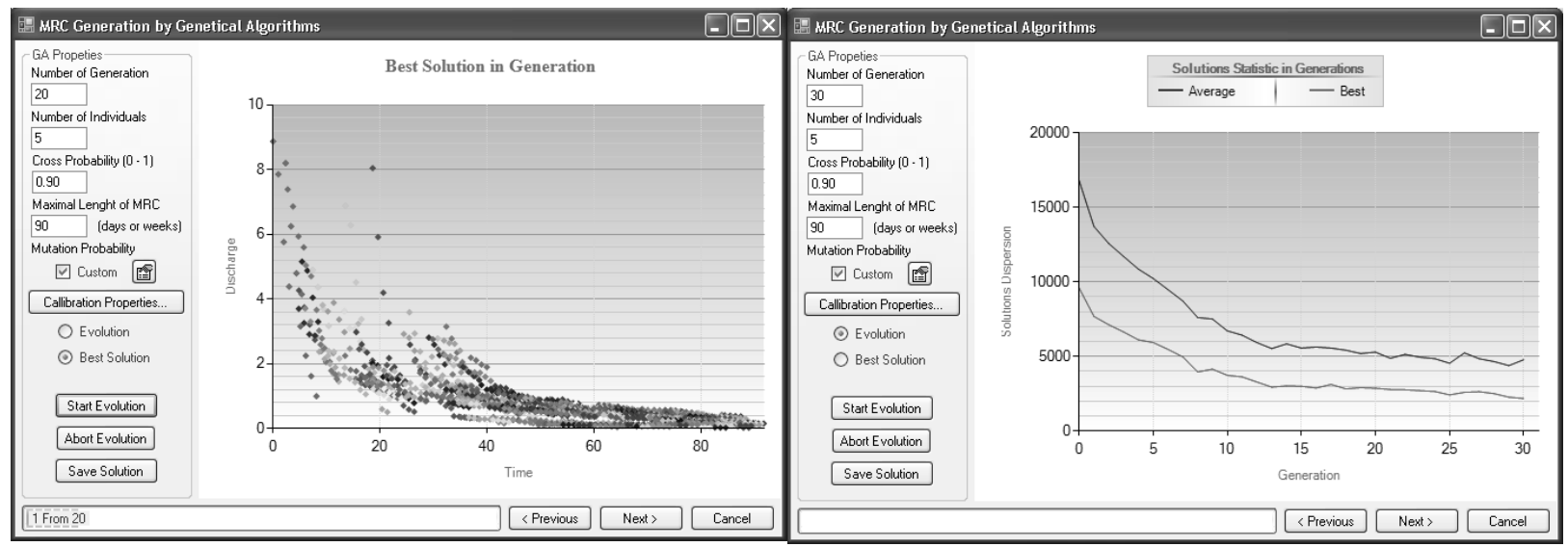

Fig. 12. Monitoring possibilities of evolution process (left - by displaying of best solution in actual generation; right - by displaying of dispersion area change in average solution and the best solution in successive generations). Individual discharge recessional successions are distinguished by points of the same colour. 


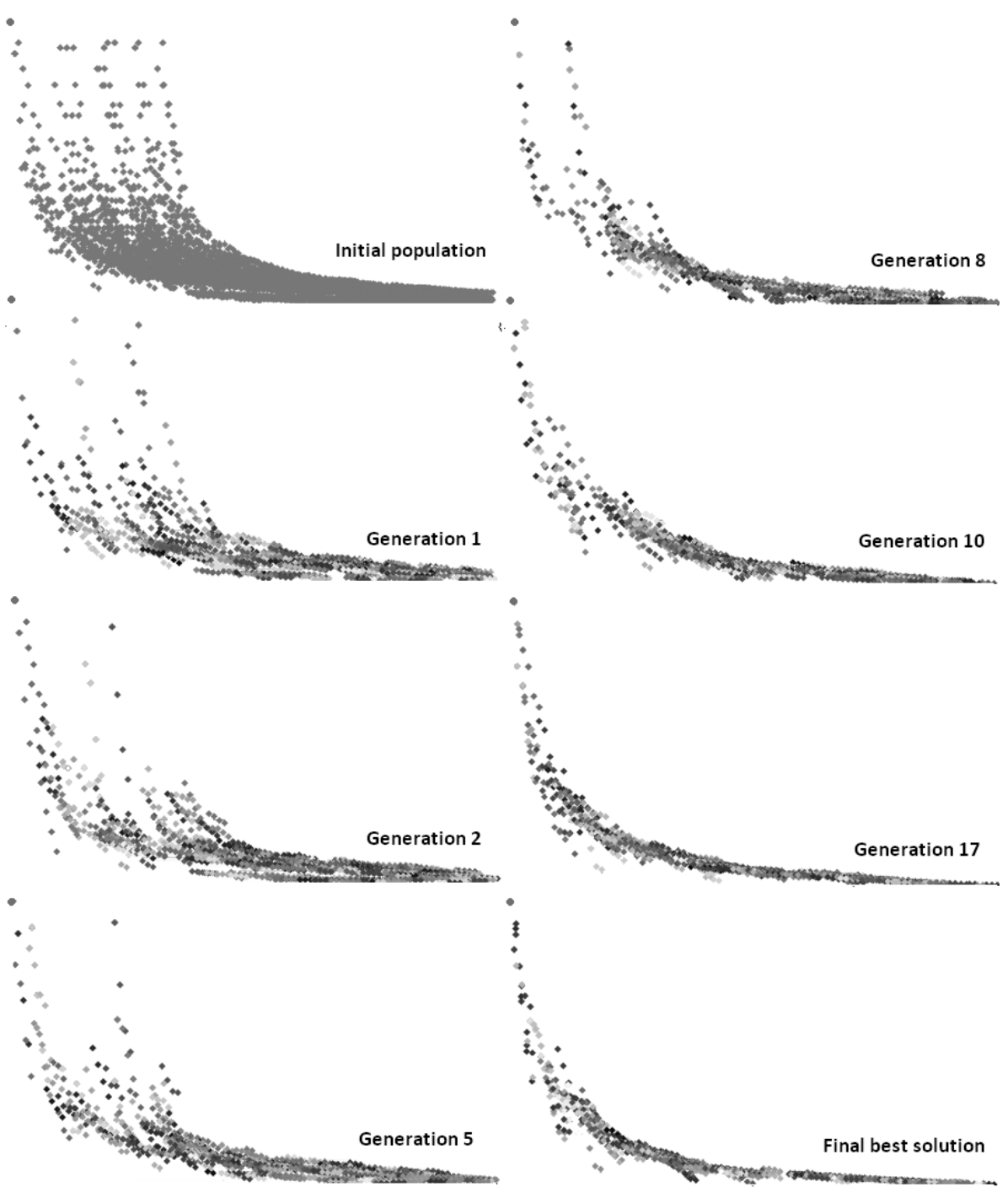

Fig. 13. Example of gradual evolutionary assembling of the most probable unaffected discharge recession sequence by the use of strongly hybridized genetic algorithm. Individual discharge recessional successions, distinguished by points of the same colour, are gradually organized.

\section{Conclusions}

Construction of a master recession curve from discontinuous recession segments is a difficult and time-consuming task. However, description of recession process by master recession curve (by formulating of corresponding equation or set of equations) is a process that can only follow the assemblage of supposed most likely natural time series of discharge recession. A new approach and computational tool described in a paper based on genetic algorithm allows creation of the most probable natural, unaffected recessional discharge sequences in time, from which the master recession curves can be constructed. Such assembling of recessional discharge time series can help us to avoid obstacles such as limited time-series datasets, incomplete recessions, too many segments in many recessional successions, complicated hydrograph shape in the case of karstic springs, different time intervals of observations (daily or weekly frequencies), short time-series intervals, imprecise measurements, different types of datasets (averaged or instantaneous data) or even rough (inaccurate) measurements of discharges. The only type of discharge data set without practical output solution of the method presented is the constant discharge value in time, which under real hydrological circumstances, however, doesn't occur frequently and surely does not represent any recession. Described algorithm was implemented into a programme solution and this implementation was successfully tested on a number of variable input discharge data in different time series. 


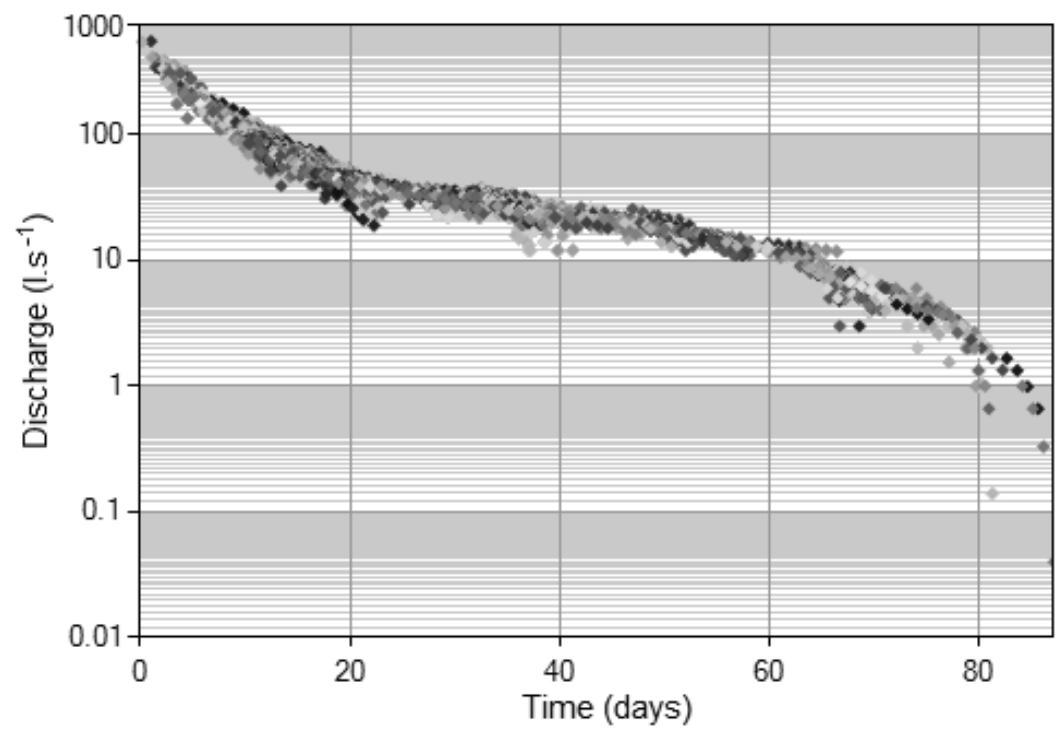

Fig. 14. Result of the most probable unaffected discharge recession sequence assembling for the Dovalka karst spring in Murán̆ (Slovakia).

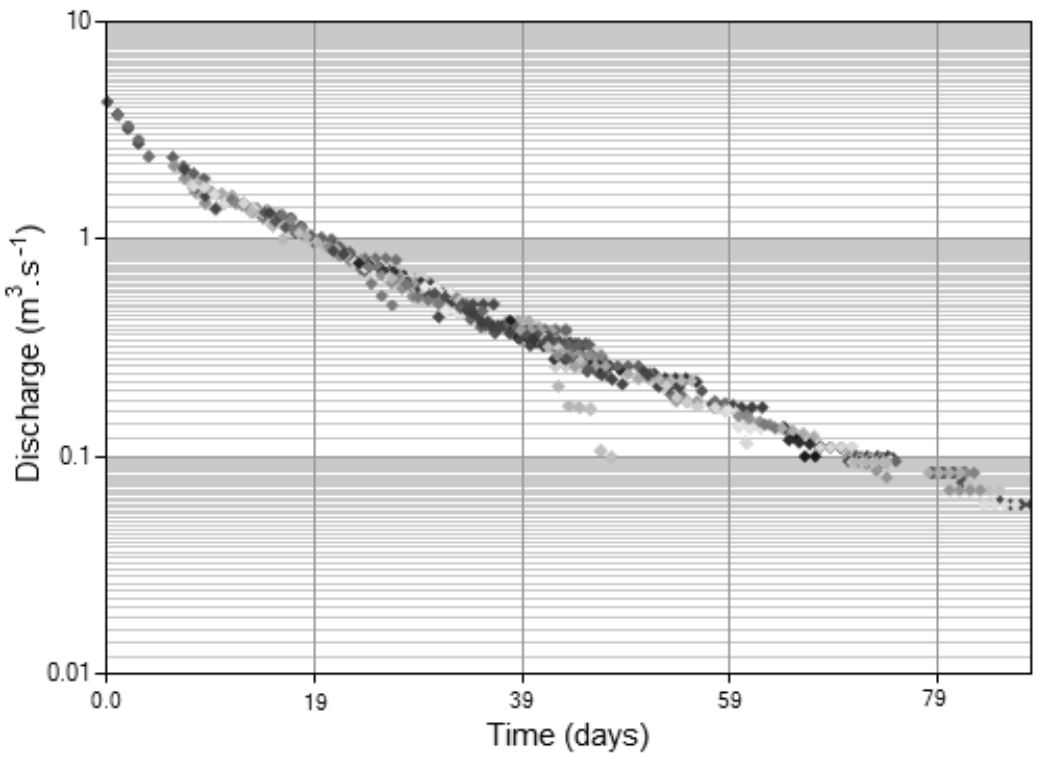

Fig. 15. Result of the most probable unaffected discharge recession sequence assembling for the Lubochnianka stream gauging in Lubochňa (Slovakia).

After its development this method has been implemented into freeware executable program that allows its direct use in practice. Applicability of strongly hybridized genetic algorithm method for assembling of the most probable unaffected natural discharge recession sequence and further master recession curve creation is therefore at hand without requirements on programming skills of hydrologists involved. It is possible to apply the evolutional assembling of the discharge recession sequences within the RC 4.0 module in the freely accessible HydroOffice software (http://www. hydrooffice.org), developed by one of the authors.

\section{REFERENCES}

BARNES B. S., 1939: The structure of Discharge-Recession Curves. Trans. Amer. Geophys. Un. Part IV, 721-725.

BAYER P., FINKEL M., 2004: Evolutionary algorithms for the optimization of advective control of contaminated aquifer zones. Wat. Resour. Res., 40, 6, pp. 19, DOI:10.1029/2003WR002675.

BOUSSINESQ M. J., 1877: Essai sur la theories des eax courantes. Memoires presentes par divers savants a l'Academie 
des Sciences de l'Institut National de France, Tome XXIII, 1.

BOUSSINESQ M. J., 1904: Recherches théoriques sur l'écoulement des nappes d'eau infiltrées dans le sol et sur le debit des sources. Journal de mathématiques, $5^{\mathrm{e}}$, serie 10.

COOPER H. H.jr., RORABAUGH M. I., 1963: Groundwater movements and bank storage due to flood stages in surface streams. USGS Water Supply Paper, 1536-J, 343-366.

CHIU Y. Ch., CHANG L. Ch., CHANG F. J., 2007: Using a hybrid genetic algorithm - simulated annealing algortithm for fuzzy programming of reservoir operation. Hydrological Processes, 21, 23, 3162-3172.

ČISTÝ M., BAJTEK Z., 2009: Hybridná metóda pre návrh distribučných systémov rozvodu vody. (Hybrid method for least-cost design of the water distribution systems.) (In Slovak with English summary.) J. Hydrol. Hydromech., 57, 2, 130-141.

DROGUE C., 1967: Essai de détermination des composantes de l'écoulemet des sources karstiques. Evaluation de la capacité de rétention par chenaux et fissures. Chronique d'Hydrogéologie, 10, Bureau de Recherches Geologiques et Miniéres, Paris.

GREGOR M., 2008: Vývoj programov na analýzu časových radov výdatností prameňov a prietokov vodných tokov. (Software development for time-series analysis of springs yields and river discharges.) (In Slovak.) Podzemná voda, 14, 2, 191-200.

HydroOffice, 2011: HydroOffice software - software for water science. Software. Modules. RC. (Online.) Available from: http://www.hydrooffice.org (Accessed 30th March 2011).

HYNEK J., 2008: Genetické algoritmy a genetické programování. Praha, Grada Publishing, 2008, ISBN 978-80-2472695-3, $200 \mathrm{p}$.

GRIFFITHS G. A., CLAUSEN B., 1997: Streamflow recession in basins with multiple water storages. J. Hydrol., 190, 60-74 .

HOLKO L., PARAJKA J., KOSTKA Z., 2003: Použitie optimalizačných metód pri modelovaní akumulácie a topenia snehu. A. Hydrol. Slovaca, 4, 1, 2003, 183-189.

HORTON R. E., 1933: The role of infiltration in the hydrological cycle. Trans. Am. Geophys. Union, 14, 446-460.

KOVÁCS A., 2003: Geometry and hydraulic parameters of karst aquifers - a hydrodynamic modelling approach. $[\mathrm{PhD}$. Thesis.] La Faculté des sciences de l'Université de Neuchâtel, Suisse, pp. 131.

KULLMAN E., 1980: L'evaluation du regime des eaux souterraines dans les roches carbonatiques du Mésozoique des Carpates Occidentales par les courbes de tarissement des sources. Západné Karpaty, sér. hydrogeológia a inžinierska geológia, 3. Geologický ústav Dionýza Štúra, Bratislava, 7-60 .

KULLMAN E., 1990: Krasovo-puklinové vody. Karst-fissure waters. Bratislava, Geologický ústav Dionýza Štúra, 1990, pp. 184.
KULLMAN E., 2000: Nové metodické prístupy k riešeniu ochrany a ochranných pásiem zdrojov podzemných vôd $\mathrm{v}$ horninových prostrediach s krasovo-puklinovou a puklinovou priepustnost'ou. Podzemná voda, VI, 2, 31-41.

LAMB R., BEVEN K., 1997: Using interactive recession curve analysis to specify a general catchment storage model. Hydrology \& Earth System Sciences, 1, 1, 101-113.

MAILLET E., 1905: Essais d'Hydraulique Souteeraine et Fluviale. Paris, Hermann Paris, pp. 218.

MALÍK P., 2007: Assessment of regional karstification degree and groundwater sensitivity to pollution using hydrograph analysis in the Velka Fatra Mts., Slovakia. Water Resources and Environmental Problems in Karst. Environmen. Geol., 51, 707-711.

MALÍK P., 2010: Separácia hydrogramu pomocou parametrov reprezentatívnej výtokovej čiary. (Hydrograph separation into flow components using parameters of the master recession curve.) (In Slovak with English summary.) Podzemná voda, $X V I, 1,113-124$

PADILLA A., PULIDO BOSCH A., MANGIN A., 1994: Relative importance of baseflow and quickflow from hydrographs of karst spring. Ground Wat., 32, 267-277.

POSAVEC K., BAČANI A., NAKIĆ Z., 2006: A visual basic spreadsheet macro for recession curve analysis. Ground Wat., 44, 5, 764-767.

RUTLEDGE A. T., 1998: Computer Programs for Describing the Recession of Ground-Water discharge and for Estimating Mean Ground-Water Recharge and Discharge from Streamflow Records - Update. Water-Resources Investigation Report 98-4148, U.S. Geological Survey, pp. 43.

SAMUEL M. P., JHA M., 2003: Estimation of Aquifer Parameters from Pumping Test Data by Genetic Algorithm Optimalization Technique. J. Irrig. Drain. Engng., 129, 5, 348-359 .

SHARMA V., SWAYNE D. A., LAM D., SCHERTZER W., 2006: Parallel Shuffed Complex Evolution Algorithm for Calibration of Hydrological Models. In: The Proceedings of the $20^{\text {th }}$ International Symposium on High-Performance Computing in an Advanced Collaborative Environment (HPCS'06), Newfoundland, 30-35.

SCHOELLER H., 1965: Hydrodynamique dans le Karst. Hydrogeologie des roches fissures. Actes du colloque de Dubrovnik 1965, IAHS-UNESCO.

TALLAKSEN L., 1995: A review of baseflow recession analysis. J. Hydrol., 165, 349-370.

TALLAKSEN L. M., van LANEN H. A. J., (Eds.), 2004: Hydrological Drought, Processes and Estimation Methods for Streamflow and Groundwater. Developments in Water Science, Amsterdam, Elsevier Science B. V., 48, pp. 579.

Received 1 April 2011 Accepted 19 October 2011 